\title{
Effect of Pozzolan and Nitrogen Fertilizer in Reducing Irrigation Water and Soil Moisture Stress in Three Eggplant Cultivars (solanum melongina)
}

\author{
Samir. G. Al-Solimani and Saleh H. Byari \\ Arid Land Agriculture Department, Faculty of Meteorology, \\ Environment and Arid Land Agriculture \\ King Abdulaziz University, Jeddah, Saudi Arabia
}

\begin{abstract}
Two field experiments were carried out during 2009 and 2010 seasons to study the effects of pozzolan, nitrogen fertilization levels, $(50,75,100$, and $125 \mathrm{~kg} \mathrm{~N} / \mathrm{ha})$ and four irrigation intervals $(2$, 4,6 , and 8 days) on fruit yield, yield components and chemical proprieties of 3 eggplant cultivars (black beauty, long purple and top bell) in a split split split plot design with three replications. The results indicated that pozzolan treatment significantly increased plant height, leaf area/ plant, no. of fruits/plant and fruit yield/ha besides total soluble solids (TSS) and vitamin C in fruit compared with the pare land (without pozzolan). Increasing irrigation interval significantly reduced plant height, leaf area/plant, no. of fruits /plant, fruit yield/ha and increased TSS, and Vitamin C in fruits. As nitrogen fertilizer increased, plant height, leaf area, no. of fruits/plant and fruit yield/ha significantly increased also TSS, and Vitamin C in fruits increased. Eggplant cultivars significantly varied in their response to pozzolan, irrigation interval and nitrogen fertilizer treatments. Black beauty cultivar significantly dominated the other cultivars in fruit yield/ ha.
\end{abstract}

Keywords: Eggplant, pozolan, nitrogen, Irrigation, Moisture stress.

\section{Introduction}

The supply of water for use in agriculture is becoming increasingly limited. Drip irrigation reduces moisture loss through evaporation and run-off, but even this conservation practice may not be adequated in dry years. Vegetable crop production in arid region is particularly sensitive to 
deficiencies of soil moisture (Thompson and Doerge, 1995). Use of rock mulch is very common in different regions to reduce evaporation. (Chesworth et al., 1983 and Fernandez and Salguero, 1987).

Mulches reduce moisture losses through evaporation and other positive effect on soil productivities and accordingly improvement of plant vigor as well as their seedlings (Groenevelt et al., 1989; Ossom et al., 2001; Diaz-Perez et al., 2004; Raemarkrishana, 2006; Kittas et al., 2006; Moreno and Moreno, 2008; and Dong et al., 2007, 2008,2009).

High nitrogen fertilizer treatments during propagation produced more rapid vegetative growth and increased yield of vegetable crops (Du et al., 1989; Allan, 1989; Khalttack et al., 2001; and Sainju et al., 2002). Increasing in discharge rate and vertical and horizontal water movement in pozzolan land compared to berlite, and particle size has an effect on moisture distribution (Shahin et al., (1999). Addition of pozzolan to the soil has resulted in a reduction of irrigation water consumption and to an increase in the growth of crops and yield (Karama and Brohi, 1995 and Shanging and Unger, 2001). Buerkert et al. (2000) in experiments lasted for 4 years found an increase in dry weight of millet, sorghum and corn due to covering soil with field crops straw. Mclntyre et al. (2000) found an increase in the biomass production in the agriculture soil covered with mulch three times that produced by uncovered soil. Covering agriculture soil with mulch straw or animal manure is accompanied with increase in plant height, crop production and biomass (Badaruddin et al., 1999).

The Objectives of this research were: (a) Using soil mulch to decrease the water consumption, (b) Using nitrogen fertilizer to increase yield and growth of 3 eggplant cultivars under different water stress treatments.

\section{Materials and Methods}

Two field experiments were conducted during 2009 and 2010 seasons at Agriculture Research Station, King Abdulaziz University at Hada Alsham to study the effect of Pozzolan as soil mulch, nitrogen fertilization rates $(50,75,100$ and $125 \mathrm{~kg} \mathrm{~N} / \mathrm{ha})$ and 4 irrigation intervals (2, 4, 6 and 8 days) on yield and yield components of three eggplant cultivars (Black beauty, Top bell and long purple). Main treatments were 2 soil mulches, sub plot treatments were 4 irrigation intervals, and the 4 
nitrogen fertilization rates were located sub sub plots, while 3 eggplants cultivar were the sub sub sub plot treatment.

A split split split plot design with three replications was used. The sub sub sub plot size was $2 \times 3 \mathrm{~m}$ and the experiments were designed according to El-Nakhlawy (2010).

The experimental site soil analysis was done before planting. Soil was characterized with 7.84 as a soil $\mathrm{pH}, 2.33 \mathrm{DSm}^{-1}$ as soil electrical conductivity (EC), $0.57 \%$ organic matters, $0.6 \%$ nitrogen $(\mathrm{N}), 0.03 \%$ phosphorus $(\mathrm{P})$ and $0.008 \%$ potassium $(\mathrm{K})$. Soil consisted from $82 \%$ sand, $15 \%$ silt and 3\% clay. The soil texture was Sand loam.

Land was prepared for planting and pozzolan $(5 \mathrm{~cm})$ was spread. Phosphorus and potassium fertilizers were added before spreading the pozzolan on the soil with $100 \mathrm{~kg}_{2} \mathrm{O}_{5} /$ ha and $100 \mathrm{~kg} \mathrm{~K} \mathrm{~K}_{2} \mathrm{O} / \mathrm{ha}$. nitrogen fertilizer (Urea) was applied with four rates $(50,75,100$ and $125 \mathrm{Kg}$ $\mathrm{N} / \mathrm{ha}$ ). Seeds were sown in mid of August and transplanted in mid of September. Drip irrigation network was used. At harvest, 10 random plants in each sub sub sub plot were used to determine plant height $(\mathrm{cm})$, leaf area/5 plants, no of fruits/plant, fruit yield ( $\mathrm{kg} / \mathrm{ha})$. Fruit yield/ha was determined as converted from the fruit yield/plot. Also chemical characteristics of total soluble solid (T.S.S) and vitamin C. of the fruit were determined.

\section{Statistical Analysis}

The obtained data of the studied factors were statistically analyzed of using analysis of variance procedures and the resulted means of the significance factor or the interaction were statistically compared with LSD at $\mathrm{P} \leq 0.05$ according to El-Nakhlawy (2010).

\section{Results and Discussion}

Significant differences were found among eggplant cultivars as regards plant height, and leaf area/5 plants $\left(\mathrm{cm}^{3}\right)$, no. of fruits/plant, fruit yield, total soluble solid (T.S.S), and vitamin C content in eggplant fruits due to the effect of pozzolan, irrigation treatment and nitrogen fertilizer rates during 2009 and 2010 seasons. 


\section{1- Effect of Pozzolan}

Pozzolan increased all traits over control treatment (no Pozzolan), plant height from 54.8 to $61.81 \mathrm{~cm}$, leaf area / 5 plants from 2752.14 to $2901.39 \mathrm{~cm} 2$, no of fruits/ plant from 19.48 to 28.02 , and fruit yield from 22217.68 to $25531.9 \mathrm{~kg} / \mathrm{ha}$. during the first season 2009 .

While Pozzolan treatment decreased TSS from 2.55 to 2.82 and 3.25 to 2.63, and vitamin C content (from 5.4 to 4.62, and from 5.01 to 4.27 in egg plant fruits under 0 and $5 \mathrm{~cm}$ pozzolan treatments, respectively, during the first season 2009. The same trends were shown in 2010 (Tables 1-3).

Table 1. Means of the plant height $(\mathrm{cm})$, Leaf area / 5 plants $\left(\mathrm{cm}^{2}\right)$ under the studied main factors during 2009 and 2010 seasons.

\begin{tabular}{|l|l|l|l|l|}
\hline \multirow{2}{*}{ Treatment } & \multicolumn{1}{l}{ Plant height (cm) } & \multicolumn{1}{l|}{ Leaf area / 5 plants Cm } \\
\cline { 2 - 5 } & $\mathbf{2 0 0 9}$ & $\mathbf{2 0 1 0}$ & $\mathbf{2 0 0 9}$ & $\mathbf{2 0 1 0}$ \\
\hline Pozzolan treatment (cm) & $54.8 \mathrm{~b}$ & $42.64 \mathrm{~b}$ & $2752.14 \mathrm{~b}$ & $2427.61 \mathrm{~b}$ \\
\hline 0 & $61.81 \mathrm{a}$ & $50.96 \mathrm{a}$ & $2901.39 \mathrm{a}$ & $2558.2 \mathrm{a}$ \\
\hline 5 & $72.99 \mathrm{a}$ & $60.23 \mathrm{a}$ & $4220.09 \mathrm{a}$ & $3722.92 \mathrm{a}$ \\
\hline Irrigation Intervals (day) & $64.44 \mathrm{~b}$ & $49.87 \mathrm{~b}$ & $3394.34 \mathrm{~b}$ & $2992.86 \mathrm{~b}$ \\
\hline 2 & $53.23 \mathrm{c}$ & $40.83 \mathrm{c}$ & $2251.62 \mathrm{c}$ & $1985.3 \mathrm{c}$ \\
\hline 4 & $42.57 \mathrm{~d}$ & $36.27 \mathrm{~d}$ & $1441.04 \mathrm{~d}$ & $1270.59 \mathrm{~d}$ \\
\hline 6 & $48.03 \mathrm{~d}$ & $43.57 \mathrm{c}$ & $1960.43 \mathrm{~d}$ & $1730.54 \mathrm{~d}$ \\
\hline 8 & $52.98 \mathrm{c}$ & $44.86 \mathrm{c}$ & $2232.96 \mathrm{c}$ & $1968.86 \mathrm{c}$ \\
\hline Nitrogen fertilization rates (kg/ha) & $63.96 \mathrm{~b}$ & $47.56 \mathrm{~b}$ & $3425.41 \mathrm{~b}$ & $3020.27 \mathrm{~b}$ \\
\hline 50 & $68.28 \mathrm{a}$ & $51.2 \mathrm{a}$ & $3688.25 \mathrm{a}$ & $3252.02 \mathrm{a}$ \\
\hline 75 & \multicolumn{5}{|l|}{} \\
\hline 100 & $49.41 \mathrm{c}$ & $38.99 \mathrm{c}$ & $3344.34 \mathrm{a}$ & $2950.26 \mathrm{a}$ \\
\hline 125 & $55.04 \mathrm{~b}$ & $47.83 \mathrm{~b}$ & $2744.49 \mathrm{~b}$ & $2419.88 \mathrm{~b}$ \\
\hline Cultivar & $70.48 \mathrm{a}$ & $53.58 \mathrm{a}$ & $2391.46 \mathrm{c}$ & $2108.61 \mathrm{c}$ \\
\hline Black beauty
\end{tabular}

* Means fallowed by the same letter of each trait under each factor are not significantly different according to LSD at $\mathrm{P}<0.05$.

Table 2. Means of the Fruit yield (Kg/ha)and no. of fruits/ plant, under the different main factors during 2009 and 2010 seasons.

\begin{tabular}{|l|l|l|l|l|}
\hline \multicolumn{2}{|c|}{ Treatment } & Fruit yield (Kg/ha) & No of fruits/plant \\
\cline { 2 - 5 } & 2009 & $\mathbf{2 0 1 0}$ & $\mathbf{2 0 0 9}$ & $\mathbf{2 0 1 0}$ \\
\hline Pozzolan treatment (cm) & $22217.68 \mathrm{~b}$ & $19917.7 \mathrm{~b}$ & $19.84 \mathrm{~b}$ & $15.44 \mathrm{~b}$ \\
\hline 0 & $25531.9 \mathrm{a}$ & $22702.9 \mathrm{a}$ & $28.02 \mathrm{a}$ & $25.16 \mathrm{a}$ \\
\hline 5 & $31990.5 \mathrm{a}$ & $28519.48 \mathrm{a}$ & $30.72 \mathrm{a}$ & $25.91 \mathrm{a}$ \\
\hline Irrigation Intervals (day) & $26284.7 \mathrm{~b}$ & $23609.13 \mathrm{~b}$ & $27.18 \mathrm{~b}$ & $23.42 \mathrm{~b}$ \\
\hline 2 & $20679.9 \mathrm{c}$ & $18418.27 \mathrm{c}$ & $21.01 \mathrm{c}$ & $17.79 \mathrm{c}$ \\
\hline 4 & $16543.9 \mathrm{~d}$ & $14734.62 \mathrm{~d}$ & $16.81 \mathrm{~d}$ & $14.08 \mathrm{~d}$ \\
\hline 6 &
\end{tabular}




\begin{tabular}{|l|l|l|l|l|}
\hline Nitrogen fertilization rates (kg/ha) \\
\hline 50 & $20153.66 \mathrm{~d}$ & $18002.1 \mathrm{~d}$ & $16.45 \mathrm{~d}$ & $19.6 \mathrm{~d}$ \\
\hline 75 & $22312.74 \mathrm{c}$ & $19938.91 \mathrm{c}$ & $22.89 \mathrm{c}$ & $19.79 \mathrm{c}$ \\
\hline 100 & $25980.3 \mathrm{~b}$ & $23211.06 \mathrm{~b}$ & $25.6 \mathrm{~b}$ & $20.12 \mathrm{~b}$ \\
\hline 125 & $27052.48 \mathrm{a}$ & $24129.41 \mathrm{a}$ & $30.77 \mathrm{a}$ & $21.7 \mathrm{a}$ \\
\hline Cultivar & $287773.89 \mathrm{a}$ & $27330.39 \mathrm{a}$ & $14.56 \mathrm{~b}$ & $12.38 \mathrm{~b}$ \\
\hline Black beauty & $25303.06 \mathrm{~b}$ & $21630.3 \mathrm{~b}$ & $43.23 \mathrm{a}$ & $36.82 \mathrm{a}$ \\
\hline Long purple & $17547.42 \mathrm{c}$ & $15000.41 \mathrm{c}$ & $13.99 \mathrm{c}$ & $11.7 \mathrm{c}$ \\
\hline Topbell
\end{tabular}

* Means fallowed by the same letter of each trait under each factor are not significantly different according to LSD at $\mathrm{P}<0.05$.

The results indicated that the application of rock mulch with pozollan gave the better performance of plants than the control treatment (without pozollan), and this may be possibility due to irrigation water saving and reduced evaporation rate from soil surface. These results are in agreement with other investigations, Box (1981) and Modiash et al., (1985); Groenevelt et al., (1989); Ossom et al., (2001); Diaz-Perez et al, 2004; Raemarkrishana, 2006; Kittas et al., (2006); Moreno and Moreno (2008); and Dong et al., (2007, 2008, 2009).

Pozzolan significantly improved plant traits (plant height, leaf area/ 5 plants). These results are similar to results of other workers such as karaman and Brohi (1995), Shanging and Unger (2001); Buerkert et al., (2000); and Mclntyre et al., (2000). Number of fruits/ plant and yield were also increased by using pozzolan and these were confirmed by Box (1981), Modiash et al. (1985) and Groenevelt et al. (1989), but pozzolan imposed significance reduction in total soluble solids (TSS) and vitamin C (Table 2).

\section{2- Effect of Irrigation Intervals}

Increasing time between the 2 successive irrigations significantly reduced all plant traits. Plant height was reduced from 72.99 at 2 days interval to $42.57 \mathrm{~cm}$ at 8 days interval, leaf area $/ 5$ plants decreased from 4220.09 to $1441.04 \mathrm{~cm}^{2} / 5$ plants, no. of fruits $/ 5$ plants from 30.72 to 16.81, and fruit yield/ha from 31990.5 to $1654.9 \mathrm{~kg} /$ ha during the first season. The same effects were showed in the second season but the means were different (Table 1\& 2).

Two and four days irrigation intervals were the best for most of fruit yield in the 2 seasons However, six and eight days irrigation interval treatments induced more water stress on plants under the study. 
However, increasing irrigation intervals increased TSS from 2.75 to 3.55 , and vitamin $\mathrm{C}$ from 4.53 to 5.49 during 2009 season and from 2.5 to 3.31, and from 4.19 during season 2010, (Table 3).

Increasing the irrigation interval reduced yield and the saved water used in plant irrigation, and imposed water stress deficit which caused reduction in plant growth and yield while reducing irrigation interval increased yield and plant traits. These results were similar to Byari (2002) and Al-Shammary (2004).

Table 3. Means of total soluble solid (T.S.S.) and vitamin $C$ of fruit under the studied main factors during 2009 and 2010 seasons.

\begin{tabular}{|c|c|c|c|c|}
\hline \multirow{2}{*}{ Treatment } & \multicolumn{2}{|c|}{$\begin{array}{l}\text { Total soluble solid } \\
\text { (T.S.S) (cmg/100). }\end{array}$} & \multicolumn{2}{|c|}{ vitamin C. of fruit. } \\
\hline & 2009 & 2010 & 2009 & 2010 \\
\hline \multicolumn{5}{|l|}{ Pozzolan treatment $(\mathrm{cm})$} \\
\hline 0 & $2.55 \mathrm{a}$ & $3.25 \mathrm{a}$ & $5.4 \mathrm{a}$ & $5.01 \mathrm{a}$ \\
\hline 5 & $2.82 \mathrm{~b}$ & $2.63 \mathrm{~b}$ & $4.62 \mathrm{~b}$ & $4.27 \mathrm{~b}$ \\
\hline \multicolumn{5}{|l|}{ Irrigation Intervals (day) } \\
\hline 2 & $2.75 \mathrm{~b}$ & $2.5 \mathrm{~b}$ & $4.53 \mathrm{~b}$ & $4.19 \mathrm{~b}$ \\
\hline 4 & $2.9 \mathrm{~b}$ & $2.7 \mathrm{~b}$ & $4.58 \mathrm{~b}$ & $4.24 \mathrm{~b}$ \\
\hline 6 & $3.55 \mathrm{a}$ & $3.32 \mathrm{a}$ & $5.43 \mathrm{a}$ & $5.03 \mathrm{a}$ \\
\hline 8 & $3.55 \mathrm{a}$ & $3.31 \mathrm{a}$ & $5.49 \mathrm{a}$ & $5.08 \mathrm{a}$ \\
\hline \multicolumn{5}{|c|}{ Nitrogen fertilization rates $(\mathrm{kg} / \mathrm{ha})$} \\
\hline 50 & $2.83 \mathrm{c}$ & $2.65 \mathrm{c}$ & $4.57 \mathrm{c}$ & $4.23 \mathrm{c}$ \\
\hline 75 & $3.01 \mathrm{~b}$ & $2.81 \mathrm{~b}$ & $4.92 \mathrm{~b}$ & 4.56 \\
\hline 100 & $3.44 \mathrm{a}$ & $3.21 \mathrm{a}$ & $5.26 \mathrm{a}$ & $4.87 \mathrm{a}$ \\
\hline 125 & $3.45 \mathrm{a}$ & $3.23 \mathrm{a}$ & $5.28 \mathrm{a}$ & $4.89 \mathrm{a}$ \\
\hline \multicolumn{5}{|l|}{ Cultivar } \\
\hline Black beauty & $3.25 \mathrm{a}$ & $3.04 \mathrm{a}$ & $4.95 \mathrm{~b}$ & $4.59 \mathrm{~b}$ \\
\hline Long purple & $3.2 \mathrm{ab}$ & $2.99 \mathrm{a} \mathrm{b}$ & $5.13 \mathrm{a}$ & $4.75 \mathrm{a}$ \\
\hline Topbell & $3.1 \mathrm{~b}$ & $2.8 \mathrm{~b}$ & $4.94 \mathrm{~b}$ & $4.58 \mathrm{~b}$ \\
\hline
\end{tabular}

* Means fallowed by the same letter of each trait under each factor are not significantly different according to LSD at $\mathrm{P}<0.05$.

\section{Effect of Nitrogen Fertilizer Rates}

Nitrogen fertilizer significantly increased all plant traits compared to control, (50kgN/ha). Plant height significantly increased from $48.03 \mathrm{~cm}$ with $50 \mathrm{~kg} \mathrm{~N} / \mathrm{ha}$ to $68.28 \mathrm{~cm}$ with $125 \mathrm{~kg} \mathrm{~N} / \mathrm{ha}$, leaf area/ 5 plants from 1960.43 to $3688.25 \mathrm{~cm}^{2}$, no. of fruits /plant from 16.45 to 30.77 and yield from 20153.66 to $27052.48 \mathrm{~kg} / \mathrm{ha}$ at 50 and $125 \mathrm{~kg} \mathrm{~N} / \mathrm{ha}$, respectively during the 2009 season. Also fruit yield/ha increased from 18002.1 to $24129.41 \mathrm{~kg} / \mathrm{ha}$ at 50 and $125 \mathrm{~kg} \mathrm{~N} / \mathrm{ha}$, respectively in 2010 season, $\mathrm{N}$ rate increased significantly TSS from 2.83 at $50 \mathrm{~kg} \mathrm{~N} / \mathrm{ha}$ to $3.45 \mathrm{Kg}$ $\mathrm{N} / \mathrm{ha}$, and fruit vitamin $\mathrm{C}$ from 4.57 to 5.28 , respectively with increase of 
$\mathrm{N}$ rate from 50 of to $125 \mathrm{Kg} \mathrm{N} /$ ha during 2009 season, and TSS from 2.25 to 3.23 , and Vitamin $\mathrm{C}$ from 4.23 to $4.89 \mathrm{~N}$ rate from 50 to $125 \mathrm{Kg}$ N/ha during the 2010 season. Similar results were found by Byari (1998); Nicklow and Migges (1962); Du et al. (1989); Fisher (1971) and Sainju et al. (2002).

\section{4- Effect of Eggplant Cultivar}

Significant differences were found among eggplant cultivars as regards, no. of fruits/plant, and fruit yield/ha during both seasons 2009 and 2010. The responses of eggplant cultivars were varied. Black beauty cultivar, had lowest no. of fruits/plant and highest yield while Long purple had highest no. of fruits/plant and had acceptable yield/ha, however, top bell produced the lowest yield (Table 1\&2).

\section{Conclusions}

Irrigation intervals imposed great stress on plants caused some flower drops and reduced the fruit set percentage accordingly and reduced yield of eggplant cultivars, two and four days irrigation intervals had better results in all studied traits. No. of fruits/plant, and fruit yield $\mathrm{kg} / \mathrm{ha}$ significantly increased as nitrogen fertilizer levels increased. Black beauty $\mathrm{cv}$. was the highest fruits yielding $\mathrm{cv}$. in the experiment.

\section{Acknowledgement}

The Project was funded by the deanship of scientific research (DSR), King Abdulaziz University Jeddah, under grant no. (7-012/924). The authors, therefore, acknowledge with thanks DSR technical and financial support.

\section{References}

Allan, R. (1989). The effect of nitrogen nutrition on growth, chemical composition and response of cucumbers (Cucumis sativus L.) to nitrogen forms in solution culture. J. Hart. Sci. 64 (4): 467-474.

Al-Shammary, A.S. (2004). Effect of water interval and some soil conditioners on growth and yield of Cucumber plant grown under greenhouse conditions. Master thesis, King Abdil Aziz Univ.

Badaruddin, M., Reynolds, M.P. and Ageeb, O.A. (1999). Wheat management in warm environments: Effect of organic and inorganic fertilizers, irrigation frequency and mulching. Agron. Journal 91: 975-983.

Box, J.E. Jr. (1981). The Effects of Surface Fragments on Soil Erosion by Water. Soil Sci. Soc. Amer. J. 45: 111-116. 
Buerkert, A.l Bationo, A. and Dossa, K. (2000). Mechanisms of residue mulch-induced cereal grown increases in West Africa. J. of Soil Sci. 64: 346-358.

Byari, S.H. (1998). Influence of irrigation with saline water on growth and fruit yield of three greenhouse Cucumber cultivars. J.K.A.U. Arid land. Agri. Sci, 9: 123-133.

Byari, Saleh, H. (2002). Potentially of Pozzolan substrates as new promising potting media compact in Horticulture. Unpublished report.

Chesworth, W., Macias V., Acquaye, D. and Thomson, E. (1983). Agricultural Alchemy: Stones into Bread. Episodes, 1: 37

Diaz-Perez, J.C., Randle. W.M., Boyhan, C., Walcott, R.W., Ciddings, O., Bertrand, O., Sanders, H.P. and Citaitia, R.D. (2004). Effects of mulch and irrigation system on sweet onion. 1. Bolting, plant growth, and bulb yield and quality. J. Am. Soc. Hortic. Sri. 129: 218-224.

Dong, H.Z., Li, W.J., Tang, W. and Zhang, D.M. (2007). Enhanced plant growth, development and fiber yield of lit transgenic cotton by an integration of plastic mulching and seedling transplanting. Ind. Crop Prod. 26: 298-306.

Dong, H.Z., Li, W.J., Tang, W. and Zhang, D.M. (2008). Furrow seeding with plastic mulching increase stand establishment and lint yield of cotton in a saline field. Agron. J. 100: 16401646.

Dong, H.Z., Li, W.J. and Zhanga, D. (2009). Early plastic mulching increases stand establishment and lint yield of cotton in saline fields. Field Crops Research. 111: 269-275.

Du, Y.C., F. Zhang M. and Liu, B.S. (1989). Effects of nitrogen type on the growth, development, yield and composition of cucumbers grown in sand culture. Acta. Hort. Sci. 16 (1): 45-50.

El-Nakhlawy, F.S. (2010). Experimental Design and Analysis in Scientific Research. Sci. Pub. Pmb. Center, King Abdul-Aziz University, Jeddah, King Saudi Arabia.

Fernandez Caldas, E. and Salguero, M.K. (1987). Mulc Farming in the Canary Islands. In: Washira \& Notholt (eds.) Agrogeology in Africa. Commonw. Sci. Counc. Tech. Pub. 226: 242-256

Fisher, K.J. (1971). Effects of nitrogen in nutrient culture on fruit yield in the first truss of the tomato. J. Hort. Sci. 46: 273-276.

Groenevelt, P.H., Van Straaten, P., Rasiah, V. and Simpson, J. (1989). Modifications in Evaporation Parameters by Rock Mulches. Soil Tech. 2: 279-285.

Karaman, M.R. and Brohi, M.P. (1995). Effect of pumice stone as a substrates on the water consumption and growth of maize at different rates. Turkish J. Forestery. 19 (5):355-300.

Khalttack, M.N., Ishtiag, M. and Naeem, N. (2001). Effect of Different Levels of Nitrogen on Growth and Yield of Different Cultivars of Eggplants Under the Agro-climatic conditions of Peshawar (Pakistan). Journal of Agriculte (Pakistan). 17(3): 339-340.

Kittas, C.M., Tchamitchian, N.K., Karaiskou, P. and Papaioannou, C. (2006). Effect of two UV-absorbing greenhouse-covering films on growth and yield of an eggplant soilless crop. Scientia Horticulturae. 110: 30-37.

McIntyre, B. D., Speijer, P. R., Riha, S. J. and Kizito, F. (2000). Effects of mulching on biomass, nutrients and soil water in banana inoculated with nematodes. Agron. Journal 92: 1081-1085.

Modiash, A.S., Horton, R. and Kirkham, D. (1985). Soil evaporation supper ession by sand mulches. Soil Sci. Col. 139:357-361.

Moreno, M.M. and Moreno, A. (2008). Effect of different biodegradable and polyethylene mulches on soil properties and production in a tomato crop. Scientia Horticulturae. 116: 256-263.

Nicklow, C.W. and Minges, P.A. (1962). Plant growing factors influencing the field performance of the fireball tomato variety. Proc. Amer. Soc. Hort. Sci. 81: 443-450. 
Ossom, E.M., Pace, P.F., Rhykerd, R.L. and Rhykerd, C.L. (2001). Effect of mulch on weed infestation, soil temperature, nutrient concentration, and tuber yield in Ipotnoea batatus (L.) Lam, in Papua New Guine \& Trop. Agric. (Trinidad) 78: 144-151.

Ramakrishna, A., Tamb, H.M., Wania, S.P. and Long, T.D. (2006). Effect of mulch on soil temperature, moisture, weed infestation and yield of groundnut in northern Vietnam. Field Crops Research 95: 115-125.

Sainju, U.M., Singh, B.P. and Whitehead, W.F. (2002) Long Term Effects of Tiliage Cover Crops. and Nitrogen ertilization on Organic Carbon and Nitrogen Concentrations in Sandy Loom Soils in Georgia USA. Soil and Tillage Research. 63(3-4): 167-179.

Shahin, U., Anapali, O. and Hanay, F. (1999). Effect of different water amount and discharge rates on moisture distribution in perlit and pumic bytrickle irrigation. Turkish J. agric. \& forestry. 23 (4999): 1010.

Shangin, M.A. and Unger, A.C. (2001). Soil water accumulation under different precipitation, potential evaporation and straw mulch conditins. Proc. Am, Soc. Hort. Sci. pp. 511-526.

Thompson, T.I. and Doerge, T.A. (1995) Nitrogen and water rates for subsurface trickleirrigation romaine lettuce. Hort. Sci. 30(6): 1233. 
تأثير البوزولان والسماد النيتروجيني في خفض مياه الري

سمير جميل السليماني، و صالح حسين بياري

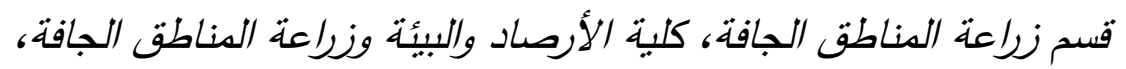

جامعة الملك عبدالعزيز، جدة، المدلكة العربية السعودية

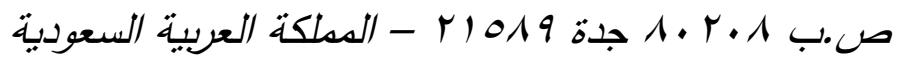

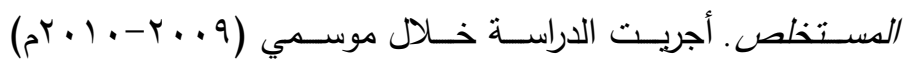

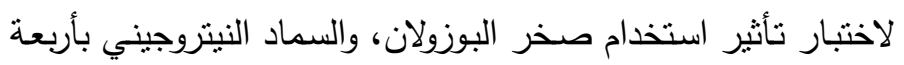

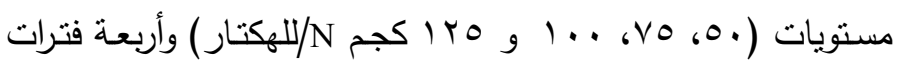

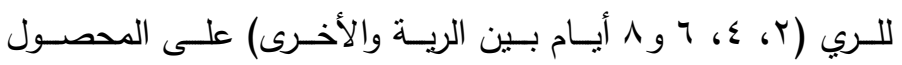

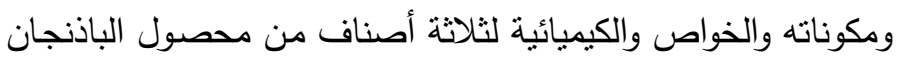
الأسود هي (Black beauty, long purple and topbell). وذلك في تصميم القطع المنثقة ثلاثة مرات (Split, Split, Split plot design)

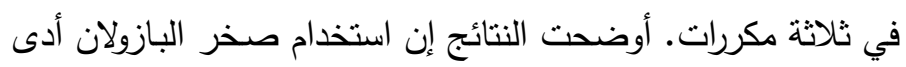

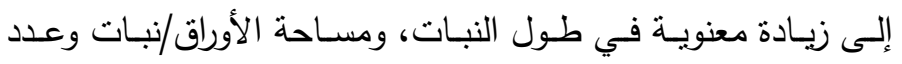

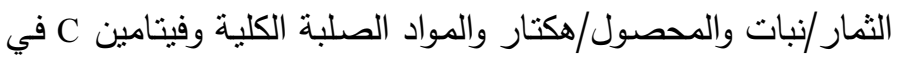

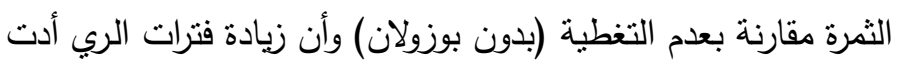

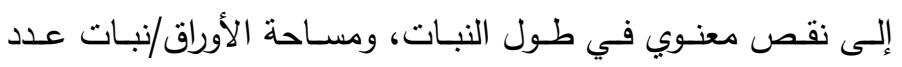
الثمار/نبات والمحصول لكنها زادت من المواد الصلبة الكلية وفيتامين

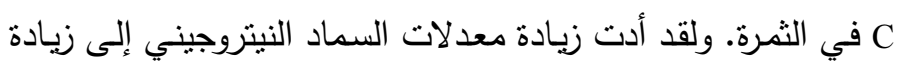

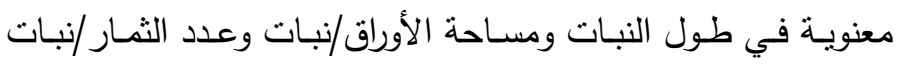
والمحصـول والمواد الصلبة الكليـة وفيتامين C في الثمـرة. وأعطى لإنى 


$$
\text { الصنف (Black beauty) أعلى محصول للثمار وذللك راجع إلى زيادة }
$$

